\title{
EFFECT OF EXTRUSION CONDITIONS ON THE PHYSICAL PROPERTIES OF HIGH PROTEIN SNACKS
}

\author{
Gamea, G.R.*
}

\begin{abstract}
Three blends were formulated from corn grits, rice grits and defatted soybean with different percentages. The blends were extruded using a single extruder with different operational conditions: temperature of the extruder ranged from 175 to $180^{\circ}$, moisture content of the raw material were $(13 \%, 15,17$ and 19\% w.b.), screw speeds were (500, 600, 700, 800, and 900 r.p.m.) and feeding rates were at (1.6, 1.8, 2 and 2.2 $\mathrm{kg} / \mathrm{min})$.Therefore, the extrudates were dried at $160 \mathrm{C}^{\circ}$ for $3 \mathrm{~min}$. Technical aspects and other physical and functional properties of the extrudates were studied.The samples were tested for sensory properties at zero time and after three months. Increasing the moisture content decreased the expansion rate while increasing both feed rate and screw speed increased the expansion rate. On the other hand increasing both moisture content and feed rate increased bulk density on contrary increasing screw speed decreased bulk density. In case of water absorption index (WAI), increasing moisture content increased WAI meanwhile increasing both screw speed and feed rate decreased WAI. As for water soluble index (WSI), increasing the moisture content, screw speed and feeding rate decreased WSI. The effect of storage (3 months) on the sensory properties including (taste, appearance, crispiness and overall acceptability) was very slightly since the scores given before and after storage were almost the same.
\end{abstract}

\section{INTRODUCTION}

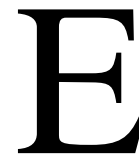

xtrusion processing has become one of the most important processing in food and feed industries. In general, extrusion cooking of food results in gelatinization of starch, denaturation of protein and lipids. The extrusion processing is defined as a technology in which a food material is forced

\footnotetext{
*Associate Professor,Department of Agricultural Engineering, Faculty of Agriculture, Minoufiya University, Egypt
} 
to flow (under one or more various conditions i.e., different moisture contents of raw materials, screw speed, feed rate, sharing and heating) through a die which is designed to form a puff-dryextrudate(Manisheat et al 1997).

The increasing popularity and rapid acceptance of extrusion technology is an important processing operation within the food, feed and starchrelated industry that has resulted due to its many advantages such as achieving high productivity in a single processing step, heating treatment of food causing denaturation of enzymes and killing microorganisms percent, improve digestibility of the food constituent by gelatinizing starch or denaturation of protein and leading to new products which improve or balance the nutritional value of some typical confectionery the starch and even protein.( Saleh, 1996 and Hamza, 1997)

Extrusion cooking is a versatile and efficient technology in the production of a wide variety of food products, such as cereal-based snack foods and ready-to-eat breakfast cereals(Ryu and Walker, 1995)

Wang, (1997) reported that, the quality of expanded snacks depends on many factors such as raw ingredients, formulation and processing conditions starch which play very important role in controlling the texture and appearance of the final product.

Frame, (1994) mentioned that, the factors affecting the extrusion process can be summarized by particle size of raw materials, moisture content, extrusion temperature, screw speed and feed rate.

In recent years much attention has been directed to the relative important of protein and energy deficits in contributing to serious public health problems in the world. Especially in the developing countries, where many social and economic factors are involved. High quality protein foods are usually expensive and beyond the reach of low income segments of the population. Thus, there is a large incidence of nutritional protein inadequacy in Egypt. Pulses, legumes and cereals on the other hand are low cost, but individually, the protein content is inadequate is some of the limiting essential amino acids. 
Corn puffs9FLIPS0 are mostly produced from corn flour. Addition of certain type of proteins can improve characteristics of food. The most often used types of proteins for enrichment of snack products are whey proteins (animalorigin) and soy protein (plant origin) (Brncic et al. $2008 \mathrm{~b}$ ). The aim of every producer is to improve the functional propertis in their new products, which implies ensuring of the basic source of nutrients (fats, proteins, minerals, vitamins, etc.)(Baskaran and Bhattacharaya,2004)

Whey proteins as a secondary ingredient enhance nutritional value of extrudates, and this is an economical approach to fortification. Despite disadvantages related to the addition of components like whey protein in extruded products, the nutritional value is increased, and this can provide other benefits for food products such as snack foods (Santillan-Moreno et al. 2009)

In Egypt and other developing countries, malnutrition could be considered as one of the problems facing community.

Cereal, Legumes and oil seeds have been as a source of protein in the diet of people from many cultures, especially where animal protein is expensive. Cereal provides about $64 \%$ of the dietary protein intake in middle East where Arabic bread is the main staple diet.

Soybean are an abundant and economical source of food protein and is used as food additive(Parks and Carpenter,1987), moreover, soybean contains a much higher protein content than other legumes and cereals. Soy protein is particularly more valuable due to its amino acid composition compliments of cereals (Tourn et al, 1981)

Protein of soybean is limiting in the sulfur containing amino acids, cysteine and methionine. The other essential amino acids are highly available, which reduce the potential value of entire amino acid balance. It contains a sufficient lysine amount, which could overcome the lysine deficiency of cereal. Fortunately, most cereal grains, as well as other vegetables products are proportionally higher in these sulfur bearing amino acid. Therefore, cereal and soybean blends possess a higher nutritional value than individual one. When soy is blended with cereals, the resulting balance of sulfur bearing amino acid with other essential 
amino acids is substantially improved. Likewise, the amino acid lysine which is very high in soybean is low in the most cereal grains. Thus, the final amino acid balance of a mixture of soybean with other products, generally improved protein nutritional value of soy and superior nutritional value than other products without soybean (Weingartenr,1993)

Rice is a principal source of calories and protein for Asians, tropical and subtropical countries. In addition, rice production has been increasing resulting in huge surpluses

Certain combinations of cereal and legumes can be very desirable from a nutritive stand point. Legumes are good sources of lysine and total protein than cereals, while cereals represent asuperior sources of sulfur amino acids. Therefore, the amino acids balance could be improved by preparing some blends of both (Almedia-Dominguez et al., 1990).

In case of soy products, extrusion serves to improve nutritional quality by inactivating certain enzymes or other ant nutritional factors. Moreover, extruded whole soybean and cereal/soy blends are good sources of flowcost protein (Ahmed et al, 1997). Therefore, it is of importance to prepare a complementary diet throughout blending some legumes and cereals, in an appreciated form to be suitable for special ages. On the other hand, it should be an adequate with respect to their economically nutritionally supports.

The main objectives of the present study can be summarized as follow:

1 - To prepare well balanced high protein snacks based on cereal and legumes including yellow corn grits, rice and defatted soybean grits using single extruder

2 - To study the effect of extrusion parameters on physical and functional properties of the extrudates product.

\section{MATERIALS AND METHODS}

\section{Materials}

All the raw materials were obtained by Egypt Foods Company, Egypt as follow: 
1. Yellow corn grits was obtained from the defranceschi Company Italy(Initial moisture contentw.b. $=12.5 \pm 0.2 \%$ )

2. Rice grits was obtained from the Egyptian Company, Tanta, Egypt (Initial moisture content, w.b.= 13.0 $\pm 0.3 \%$ )

3. Defatted soy grits was obtained from Agricultural Research Center, Giza, Egypt and ground by Misr Food Additives Company, Tanta, Egypt.( initial moisture content, w.b. = $8.5 \pm 0.3 \%)$

Three blends were formed from the raw materialsas follow:

BlendNo (1) consists of (100\% corn grits)

Blend No (2) consists of ( $65 \%$ corn grits $+20 \%$ rice grits $+15 \%$ defatted soy grits)

Blend No (3) consists of $(55 \%$ corn grits $+20 \%$ rice grits $+25 \%$ defatted soy grits)

For each blend, the calculated amount of each ingredient was weighed and all ingredients were blended using an electric mixer for $10 \mathrm{~min}$. A total weight of each blend was $50 \mathrm{~kg}$. Appropriate amount of water was added to each blend to equilibrate the water content in all blends at required level.The extrusion was performed on single extruder (ADVANTAGE 50 back type) by AMERICAN EXTRUSION INTERNATIONAL at different extrusion operation conditions as follow:

1. Feed moisture content $(13 \%, 15 \%, 17 \%$ and 19\%w.b. )

2. Screw speed $(500,600,700,800$ and $900 \mathrm{rpm})$

3. Feeding rate $(1.6,1.8,2$ and $2.2 \mathrm{~kg} / \mathrm{min})$

The temperature of cooking zone was $\left(175-180{ }^{\circ} \mathrm{C}\right)$. After extrusion the extruded blends were dried at $160^{\circ} \mathrm{C}$ for 2 to $3 \mathrm{~min}$ by belt conveyor oven diesel oil burner. The dried extrudates were chosen randomly to analyses the physical and functional properties.

A chemical composition for raw materials, blends before and after extrusion were analyzed for protein, fat, carbohydrate, ash and fiber. 


\section{$\underline{\text { 2. Equipments }}$}

All the equipment used to prepare the four studied blends were existed at "Egypt Foods Company" as follow:

\section{Single Extruder}

Extrusion was carried out using anadvantage 50 back single Extruder (American Extrusion type)with vibro stainless steel feed hoper with vibrator and screw auger for easy metered flow of raw materials, quit direct drive, speed control of main drive via inverter.Motors are efficient inverter duty, inverter supplied with extruder. Both heating and cooling temperature control. Control panel includes switchgear, AC inverters, controls and display for die temperature, digital apmeter and tachometer for main screw speed.Toal energy consumption: $36.5 \mathrm{KW}$, Horse Power Main Drive: $50 \mathrm{Hp}$. The extruder was allowed to warm-up for $20 \mathrm{~min}$ with warm up meal and to stabilize for $10 \mathrm{~min}$ with treatment meal before data collection.

\section{Dryer}

The model 3000Dryer American Extrusion passes hot dry air through the product travels through the oven this efficiently dries the products in 2 to 6 minutes. Pelt conveyor diesel oil burner was used to raise drying air temperature around $\left(130-190^{\circ} \mathrm{c}\right)$.

\section{Measurments}

Water absorption index (WAI) and water solubility index(WSI) are determined with the method developed for cereal. Extrudates were milled in a ball mill with the commercial name "Retsch mixer mil M.M. 301", Retsch GmbH, Germany. A0.1 g milled and sieved sample(mesh size 0.6 $\mathrm{mm}$ ) was used per sample. Fragmented extrudate was suspended in water at room temperature (about $22^{\circ} \mathrm{c}$ ). After $30 \mathrm{~min}$, it was centrifuged for 10 min at $3000 \mathrm{rpm}$ (centrifuge Hettich EBA 3s, Germany). Supernatant was carefully transferred into the drying vessel, and leftover of gel in cuvette is weighted. WAI was calculated using Eq. 1. Supernatant was dried at $105{ }^{\circ} \mathrm{c}$, and WSI was calculated using Eq. 2. Result is expressed as percent of dry matter (Eq.3; Stojceska t al. 2009) 

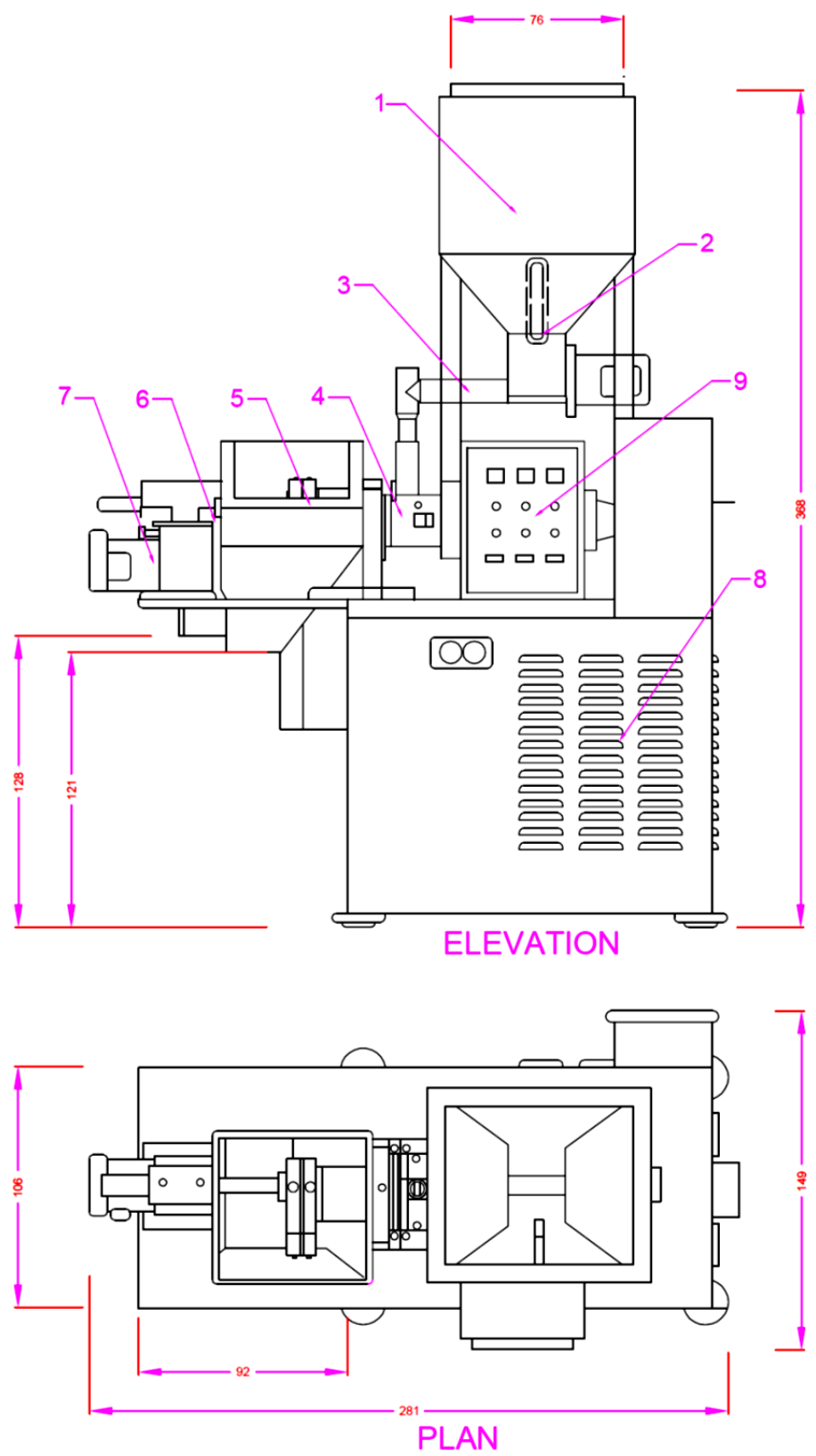

DIMS. IN cm

1.hopper feed

2. gate

3.mixing cylinder 4.feeding zone

5.barrel

6.duble die 7.knife blade

8.drive gear reducer

9.elecric motor

Figure 1. Sketch of advanced back type single extruder. 
$\mathrm{WAI}=\mathrm{m}(\mathrm{gel}) / \mathrm{m}($ dry mater of sample $)$

$\mathrm{WSI}=\mathrm{m}$ (supernatant) $/ \mathrm{m}$ (dry mater of sample)

$\mathrm{m}($ dry mater $)=\mathrm{m}($ sample $)-\{(\mathrm{m}($ sample $) \times(\%$ of water $) / 100\}$

Expansion index (EI) was determined as described by Ryu and $\mathrm{Ng}$ (2001). The EI calculated as the diameter of extrudates divided by the die diameter. The diameter of extrudates was measured at three different positions along the length of each of the ten random samples using vernier caliper.

Bulk density was determined according to the method described by Gujska and Khan $(1991 \mathrm{~b})$. bulk density $\left(\mathrm{mg} / \mathrm{cm}^{3}\right)=$ extruded weight / extruded volume. Volume was measured by using graduate cylinder.

Proximate chemical analysis was carried out in food analysis laboratory, food science department, minoufiyaUniversity,Egypt as follow:

Moisture content \% w.b. (method No. 32.1.03), protein (method No. 32.1.22), crude fiber (method No. 32.1.15), crude fat (method No.32.1.13), and total ash (method No.32.1.05) were determined in raw materials and extrudates samples as described in the A. O. A. C. (1995). Total carbohydrates content were calculated bythe following equation:

Total carbohydrates $\%=100-($ protein $\%+$ lipids $\%+$ ash $\%+$ fiber $\%+$ moisture\%)

Organoleptic characteristics were carried out according to the method described by Bates et al. (1991).Apanel of 10 members were asked to evaluate the quality of snacks formulas using a composite scoring test. The tested samples were presented in a randomized order to the panelists to evaluate the taste, color, appearance, texture and overall acceptability using a scale ranged as Follow:(8.6 - 10) excellent, (7.6 - 8.5)good, (6.1 - 7.5) fair and (5.0 6.0) poor.

\section{Statistical analysis}

Data obtained were statistically analyzed using complete randomized factorial design for different blends (SPSS, version 13). All percentage data were converted to the corresponding arcsine prior statistical analysis. Data were expressed as the mean of three separate determinations. When a significant main effect was detected, the means separated. Significance was assumed at $(0.05>p)$. 
PROCESS ENGINEERING

\section{RESULTS AND DISCUSSIONS}

\section{Expansion index}

Mean effect of different levels of moisture content d.b. (13, 15, 17 and $19 \%$ ) of three different blends on the expansion rate is presented in figure 2.Blnd No 1 consists of $100 \%$ corn, blend No 2 consists of $65 \%$ corn, $20 \%$ rice and $15 \%$ defatted soy bean and blend No 3 consists of $55 \%$ corn, $20 \%$ rice and $25 \%$ defatted soy bean.

The results indicated that increasing moisture content to $19 \%$ of the blend 1, 2 and 3 caused significant decrease of the expansion rate by 25 , 11 , and $14 \%$ respectively. This may be due to the reduction of temperature intake and degree of starch gelatinization. In spite of the highest expansion ratio which was obtained at moisture content $13 \%$, the blend 2 and 3 were dry, dark in color and bad appearance, while corn had very good appearance. Incorporation of defatted soy bean in blends caused significant decrease of expansion rate at all levels of moisture content. The obtained results are agreement with those found by El Dash (1985) and Kabil (2007). They reported that the expansion rate of final extrudate products increased with decreasing the moisture content of the feed material. The highest expansion rate attained at $15-16 \%$ misture content while the lowest expansion rate attained at $22-25 \%$ moisture content.

Results dealing with the mean effect of the screw speed $(55,600,700$, 800 and $900 \mathrm{rpm}$ ) on the expansion rate of the blends are presented in figure 3 . These results indicated that the maximum expansion rate of corn extrudates was obtained at screw speed $800 \mathrm{rpm}$ followed by 700 and $900 \mathrm{rpm}$, while the screw speed $500 \mathrm{rpm}$ gave the lowest expansion rate. At $900 \mathrm{rpm}$ screw speed expansion rate decreased and sample shape started to be irregular. This may be due to the increments of the screw speed and the heat friction that increased the temperature intake followed reduced in the viscosity. It was explained byChaiyakul et al. (2009), that melt viscosity decreased with increased temperature and the reduced viscosity effect would favor the bubble growth during extrusion. While high screw speed decreased of the residence time in extruder causing decreasing of the starch gelatinization. 


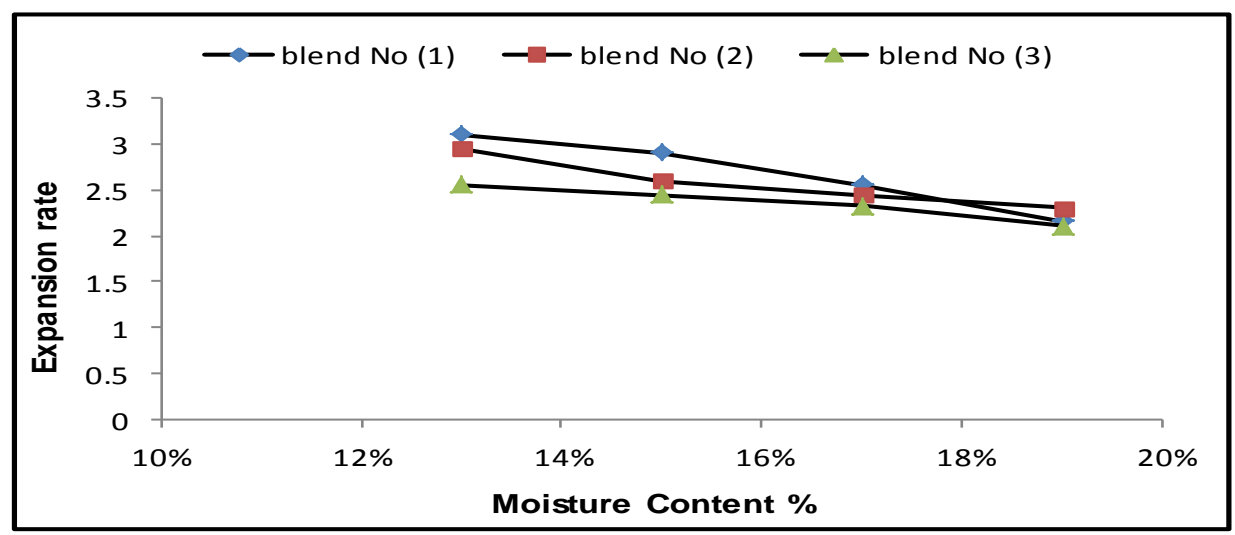

Fig. 2. Effect of Moisture content on expansion rate of extrudates.

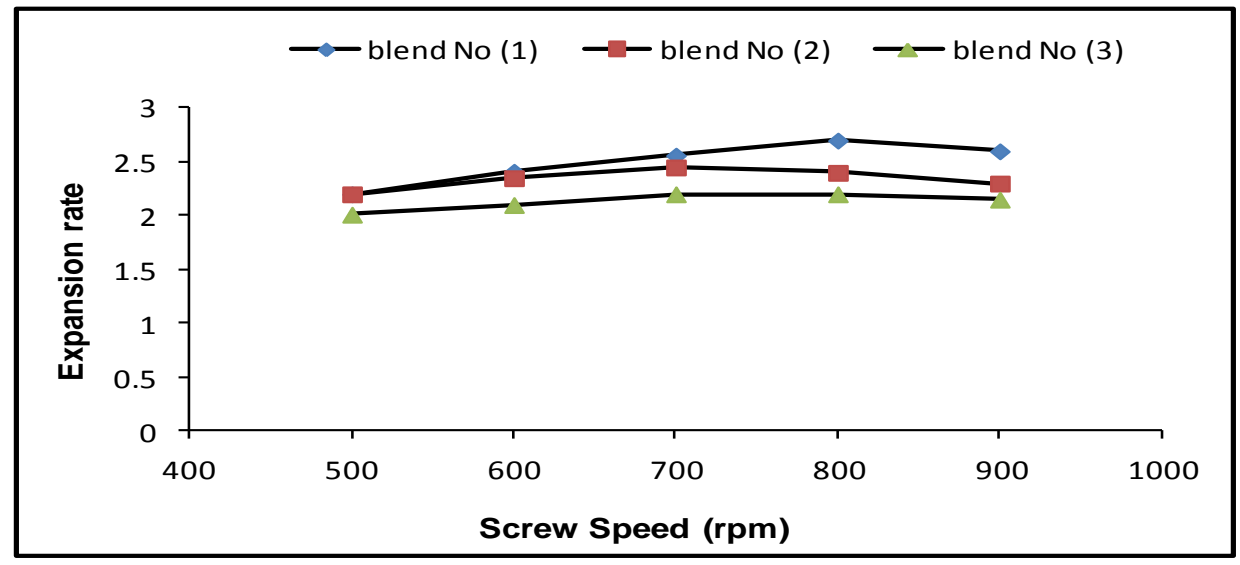

Fig. 3. Effect of screw speed on expansion rate of extrudates.

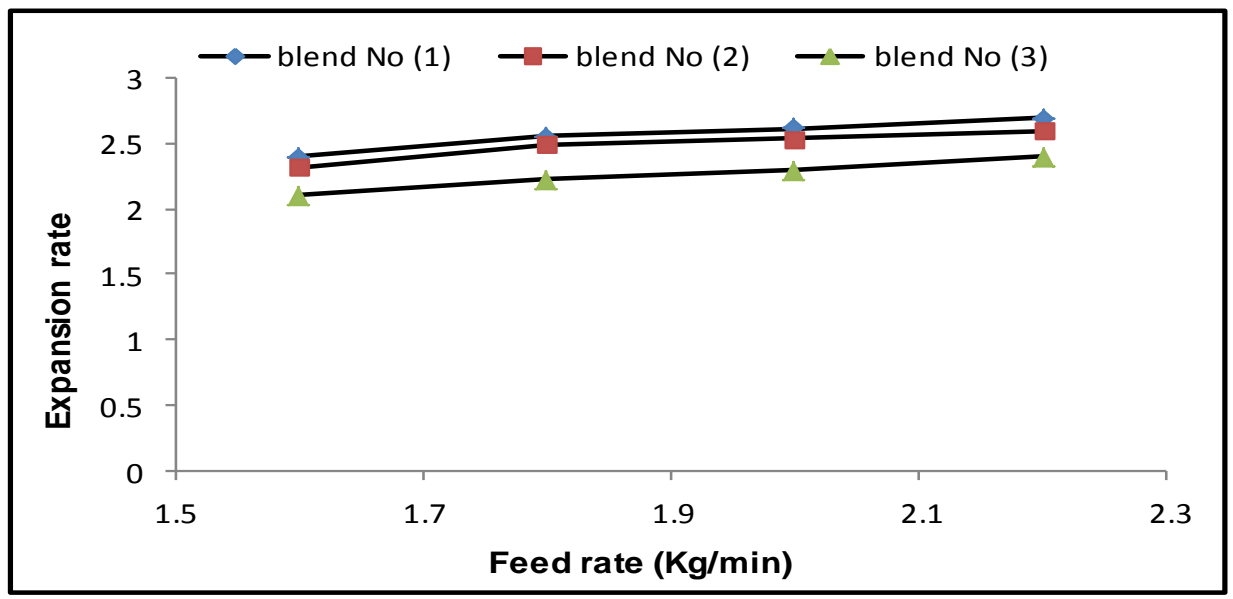

Fig. 4. Effect of feeding rate on expansion rate of extrudates. 
Results concerning the effect of feed rate (1.6, 1.8, 2, and $2.2 \mathrm{~kg} / \mathrm{min})$ are presented in figure 4. Results indicated that the expansion rate of the three blends increased with increasing the feed rate but this increasing was not significant. Increasing value of expansion rate with increasing of feed rate may be due to the increase of friction between the screw and the stator that increased temperature intake and the degree of starch gelatinization. The blend No 3 had the lowest expansion rate at different feed rate, these may be due to increase the percentage of soy bean $(25 \%)$.

Overall, the analysis of obtained data revealed that the moisture content of the blend and screw speed had a significant effect on expansion rate, while the feed rate had insignificant effect on expansion rate among the three blends. Also, increasing the percentage of defatted soy bean had a significant effect on the expansion rate.

\section{$\underline{\text { 2. Bulk Density(BD) }}$}

The bulk density is very important in the production of expanded and formed food products.

Data obtained and figure 5 indicated that the bulk density of the blends (1) , (2) an (3) increased with the moisture content increased to $19 \%$ by $30.53,33.91$ and $41.9 \%$ respectively. This may due to the relation between the moisture content and temperature intake, starch gelatinization. Higher temperature provided a higher potential energy for flash-off of superheated water from extrudates as they left the die. With higher intake temperature, the extrudates exiting the die lose more moisture and become lighter in weight(Koksel et al., 2004).

Increasing the percentage of defatted soy bean increased bulk density of the extrudates. The bulk density of the blend No (2) and (3) increased by 12.5 and $30 \%$ compared to blend No (1) at $15 \%$ moisture content, by 14.8 and $48.5 \%$ at $17 \%$ moisture content and by 18.8 and $41.05 \%$ at $19 \%$ moisture content. These results may be due to increasing the protein content of denaturized soy bean during extrusion process by using high temperature and short time cooking.

Figure 6 show the relation between the screw speed (rpm) and the bulk density of the extrudates. It could be noticed that increasing the screw 
speed decreased the bulk density with the different levels of other variables. Also it could be observed that increasing percentage of defatted soy bean from 15 to $25 \%$ had significant increase in the bulk density of the extrudates. This could be ascribe to increase screw speed that decreased the resident time which in turn definitely affect the gelatinization process of starch. Also, increasing defatted soybean increased both the protein and the crude fiber which had an increasing effect on bulk density.

Data analyzed and figure 7 indicated that there was a significant increase of bulk density for the blends (1), (2) and (3) with increasing of feeding rate. The lowest bulk density was $43.19 \mathrm{mg} / \mathrm{cm}^{3}$ with corn at $1.6 \mathrm{~kg} /$ min feed rate and the highest bulk density was $69.50 \mathrm{mg} / \mathrm{cm}^{3}$ at 2.2 feed rate with the blend No (3) which contained $25 \%$ defatted soybean. It could be noticed that the feed rate had obvious effect on bulk density with increasing defatted soybean. This may be due to the increase of protein and fiber content by increasing the defatted soybean ratio.

Statistical analysis revealed that, moisture content of the extrudate, screw speed and feed rate had significant effect on bulk density. Also, the increasing percentage of defatted soy bean had significant effect on bulk density.

\section{Water Absorption Index (WAI)}

Figure 8 revealed that increasing the moisture content up to $19 \%$ increased water absorption index of the three extrudate blends(1), (2) and 3 by 51, 29 and $27 \%$ respectively. Also it could noticed that, there was an increase in WAI by increasing percentage of defatted soybean, these could be referred to the increase of protein and fiber contents.

Figure 9 show that with increasing screw speed up to $900 \mathrm{rpm}$ the WAI of the blends(1), (2) and (3) were decreased by about 54, 44 and 30\% respectively. This may be due to the percentage of soybean in the blends which led to decrement of WAI, consequently reducing the residence time of samples in the extruder. These results are in agreement with those found by Ragab (1992). 


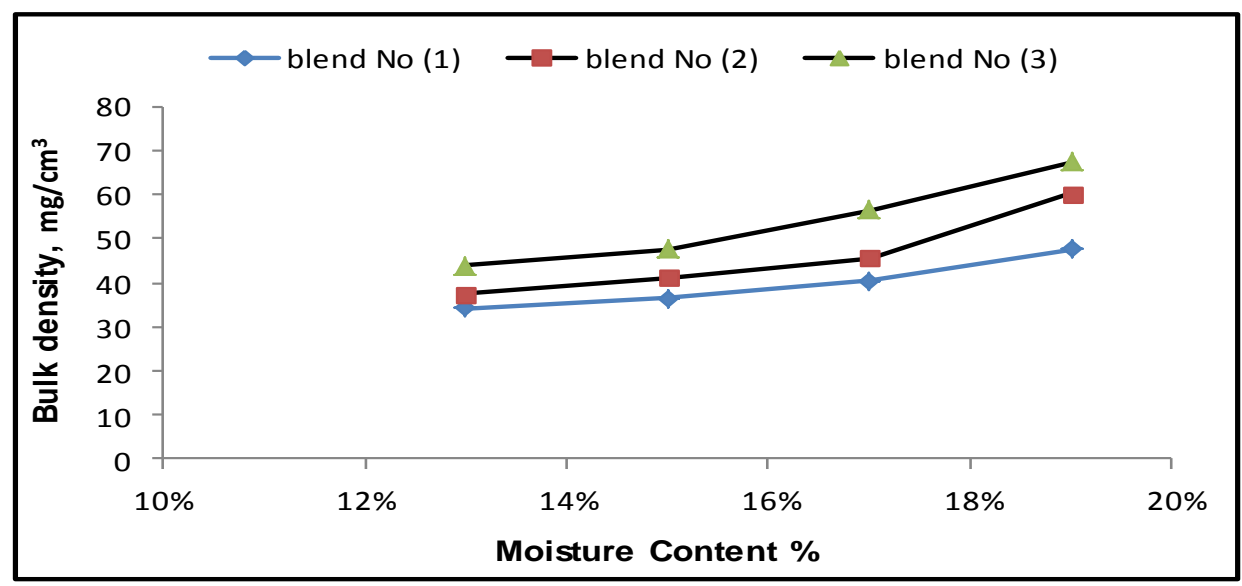

Fig.5. Effect of Moisture content on bulk density of extrudates.

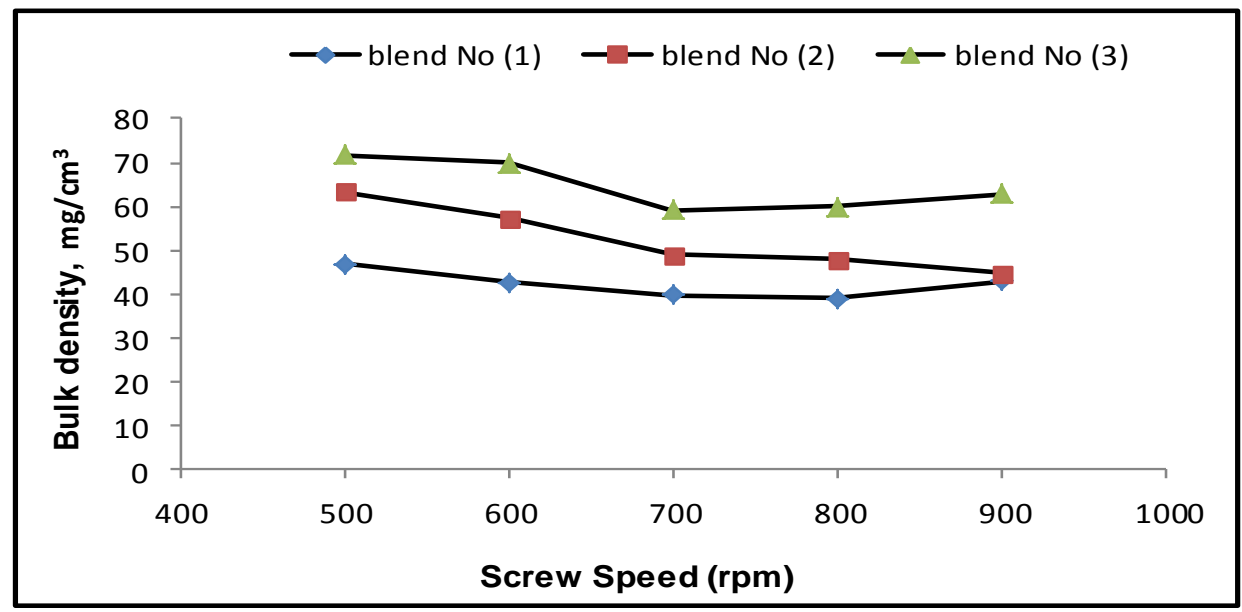

Fig.6. Effect of screw speed on bulk density of extrudates.

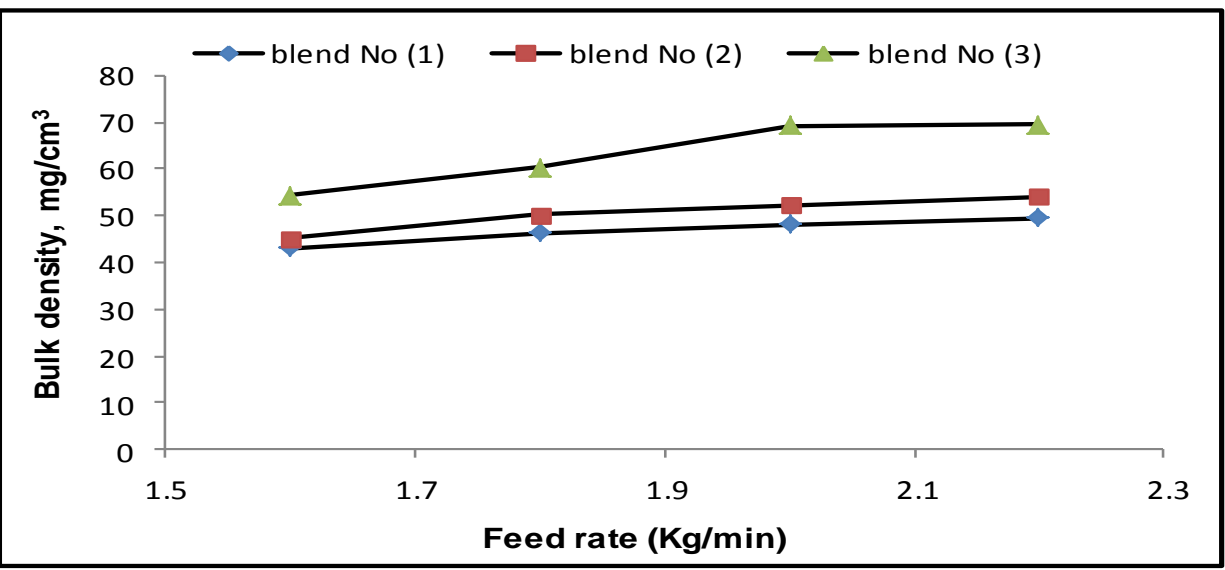

Fig.7. Effect of feeding rate on bulk density of extrudates. 
Figure 10show the effect of feed rate on WAI of extrudates. It was found that increasing feed rate to $2.2 \mathrm{~kg} / \mathrm{min}$ decreased the WAI by 37,19 and $17 \%$ respectively. This was mainly due to increasing quantity of material per volume of extruder which directly affect the WAI.

Statistical analysis of data revealed that moisture content of the extrudate blends, screw speed and fed rate had significant effects on WAI. Also, increasing in percentage of defatted soy bean had significant reduction effects on WAI.

\section{Water Solubility Index (WSI)}

Figure 11 show the effect of moisture content on the WSI of the extrudate blends. The results indicated that increasing the moisture content up to $19 \%$ decreased the WSI of the blends (1), (2) and (3) by 17, 18and 23\% respectively. These results are in agreement with RAgab (1992) and Kabil (2007). Data also revealed that the blend (2) and (3) had WSI lower than extrudate corn $100 \%$, this may be due to the percentage of defatted soybean in these blends.

Figure 12indicated that with increasing screw speed from 500 to $900 \mathrm{rpm}$ the WSI decreased from 22.47 to 16.69 of corn extrudates, from 19.7 to 14.06 of blend No (2) and from 17.89 to 11.43 of blend No (3). It could be observed that increasing percentage of defatted soybean decreased the WSI due to increasing protein content. Also, the effect of increasing the screw speed on decreasing the WSI may be due to the increasing of heat friction and that in turn would affect the WSI.

Figure 13show the effect of feed rate on WAI of extrudates. It was found that increasing feed ratecaused sharp decrease in WSI. This could be ascribed to decreasing the resident time of the blends in the extruder which directly affect the temperature and in turn decreased the WSI. Also increasing the soybean ratio translated to increase of protein and fiber content which decrease the WSI.

Statistical analysis of data revealed that moisture content of the extrudate blends, screw speed and fed rate had significant effects on WSI. Also, increasing in percentage of defatted soy bean had significant reduction effects on WSI. 


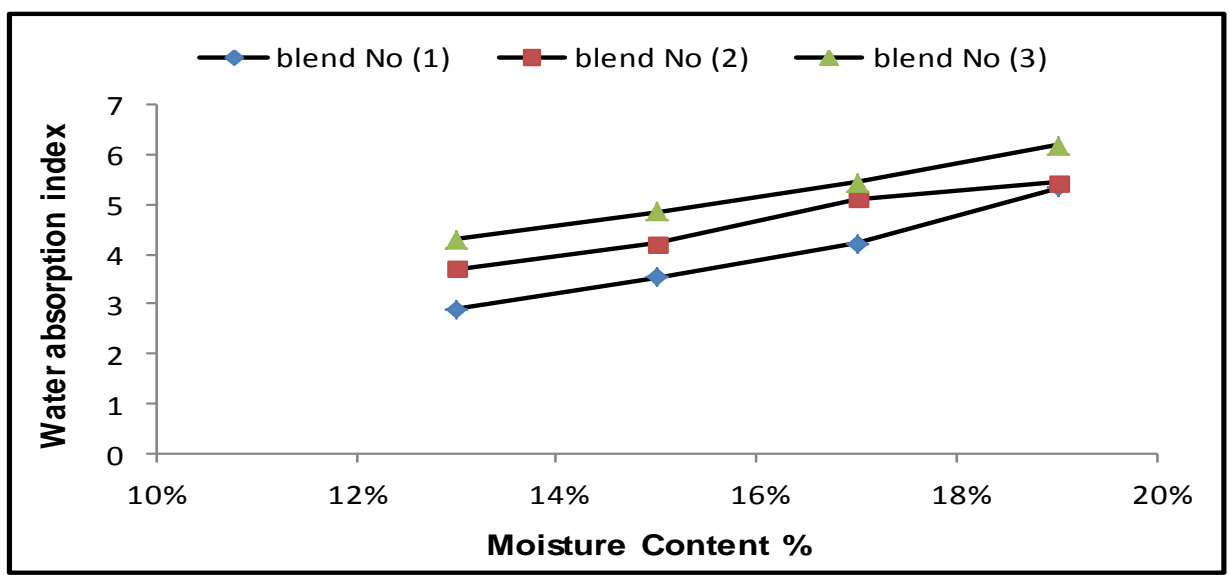

Fig.8. Effect of moisture content on water absorption index of extrudates.

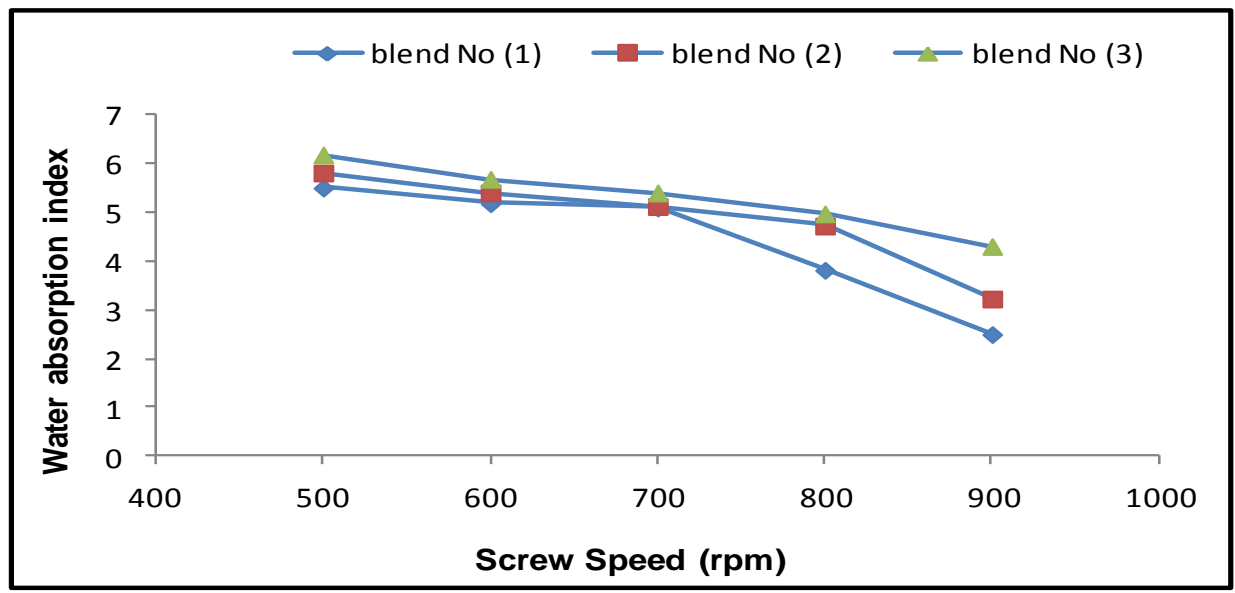

Fig.9. Effect of screw speed on water absorption index of extrudates.

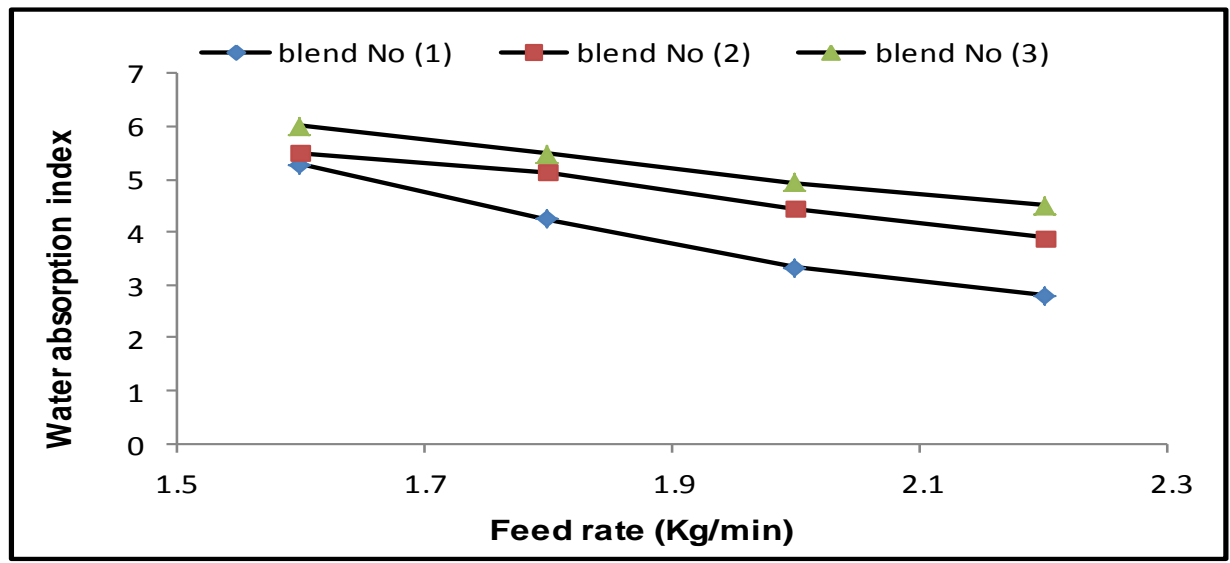

Fig.10. Effect of feeding rate on water absorption index of extrudates. 
Regression statistical analysis were conducted to clarify the relationship between physical properties of extrudates and operating variables. The regression appeared a linearly dependent on the operating variables. The following equations represent the relationships:

$$
\begin{array}{ll}
\mathrm{EI}=-0.108 \text { M.C. }+4.282 & \mathrm{R}^{2}=0.9931 \\
\mathrm{EI}=0.001 \text { S.S. }+1.637 & \mathrm{R}^{2}=0.9323 \\
\mathrm{EI}=0.445 \text { F.R. }+1.597 & \mathrm{R}^{2}=0.9324 \\
\mathrm{BD}=2.625 \text { M.C. }+3.775 & \mathrm{R}^{2}=0.9764 \\
\mathrm{BD}=-0.0425 \text { S.S. }+82.187 & \mathrm{R}^{2}=0.9546 \\
\mathrm{BD}=16.77 \text { F.R. }+21.37 & \mathrm{R}^{2}=0.9690 \\
\text { WAI }=0.368 \text { M.C. }-1.243 & \mathrm{R}^{2}=0.9882 \\
\text { WAI }=-0.004 \text { S.S. }+8.086 & \mathrm{R}^{2}=0.9439 \\
\text { WAI }=-2.95 \text { F.R. }+10.13 & \mathrm{R}^{2}=0.9388 \\
\text { WSI }=-1.092 \text { M.C. }+34.492 & \mathrm{R}^{2}=0.9584 \\
\text { WSI }=-0.014 \text { S.S. }+27.135 & \mathrm{R}^{2}=0.9736 \\
\text { WSI }=-10.92 \text { F.R. }+37.76 & \mathrm{R}^{2}=0.9584
\end{array}
$$

Chemical composition of raw materials indicated that, defatted soybean grits had the highest crude protein content $51.2 \%$ followed by rice grirs 8.55 while the corn grits hade the lowest crude protein $0.8 \%$. The highest level of ash was $6.8 \%$ in defatted soybean followed by both corn 0.3 and rice $0.3 \%$, while the highest amount of carbohydrates was $90.5 \%$ in corn followed by rice $90.0 \%$ and lowest carbohydrates content was $32.8 \%$ in defatted soybean. Defatted soy bean could be considered a good source of protein, fiber and minerals, while corn and rice provided excellent sources of carbohydrates.

A comparison of the nutrient composition of the blends before and after extrusion revealed that, the extrusion caused a decrease in protein, fat and moisture decrement percentage in all the blends were (4.6 to $7.2 \%, 45.0$ to $60.0 \%$ and 53.5 to $58.8 \%$ ) respectively, while ash, fiber and carbohydrates increased in all the blends by (6.1 to $12 \%, 4.2$ to $7.1 \%$ and 1 to $3 \%$ ) respectively. 


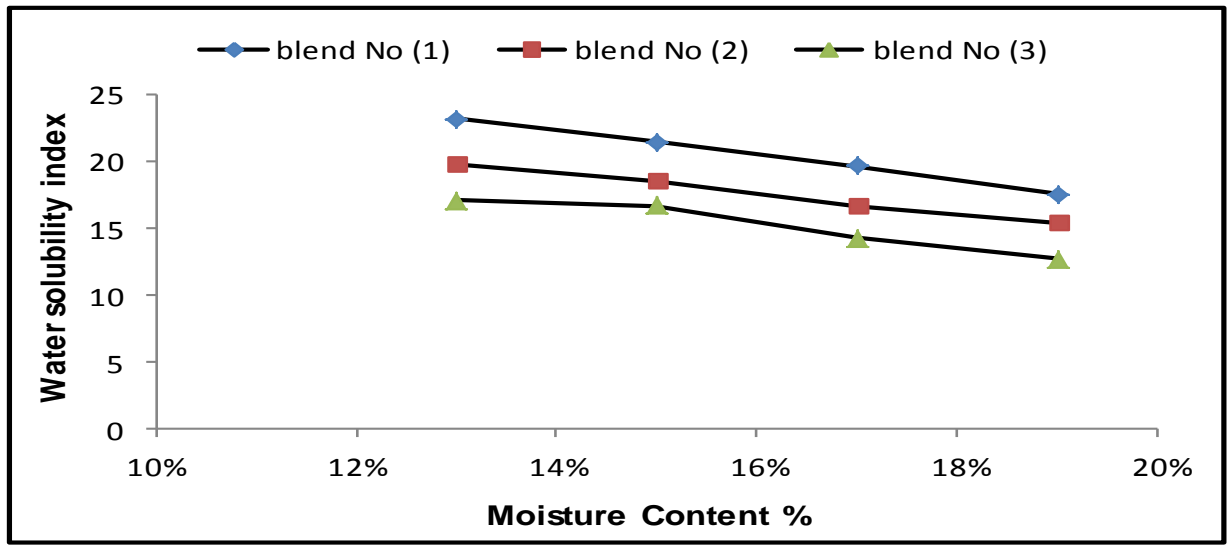

Fig. 11. Effect of Moisture content on water solubility indexof extrudates.

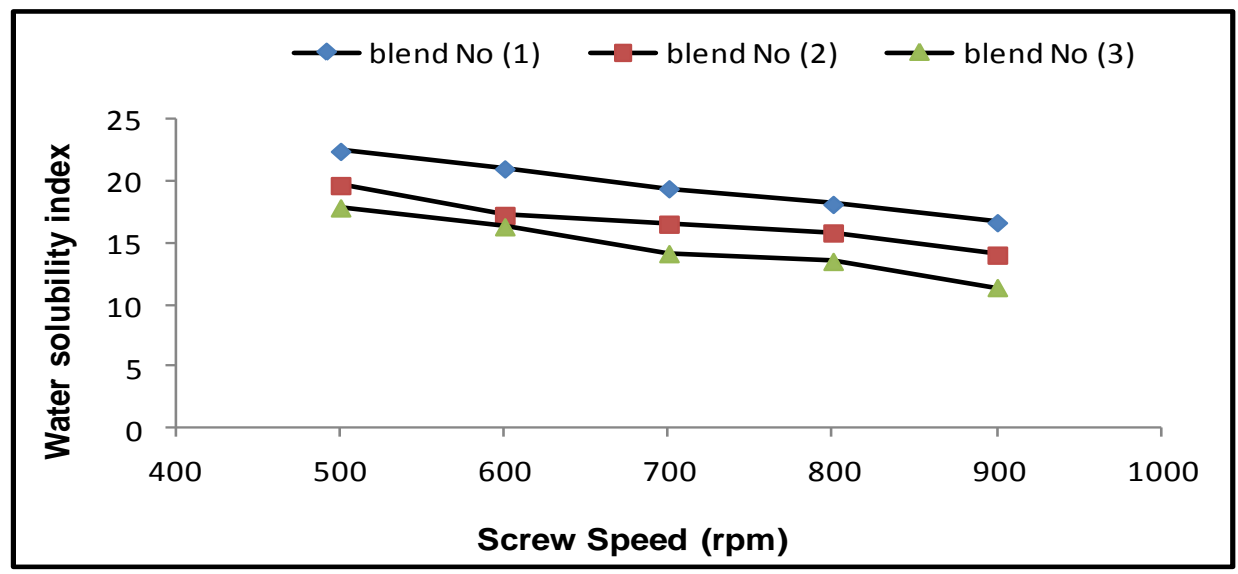

Fig.12. Effect of screw speed on water solubility index of extrudates.

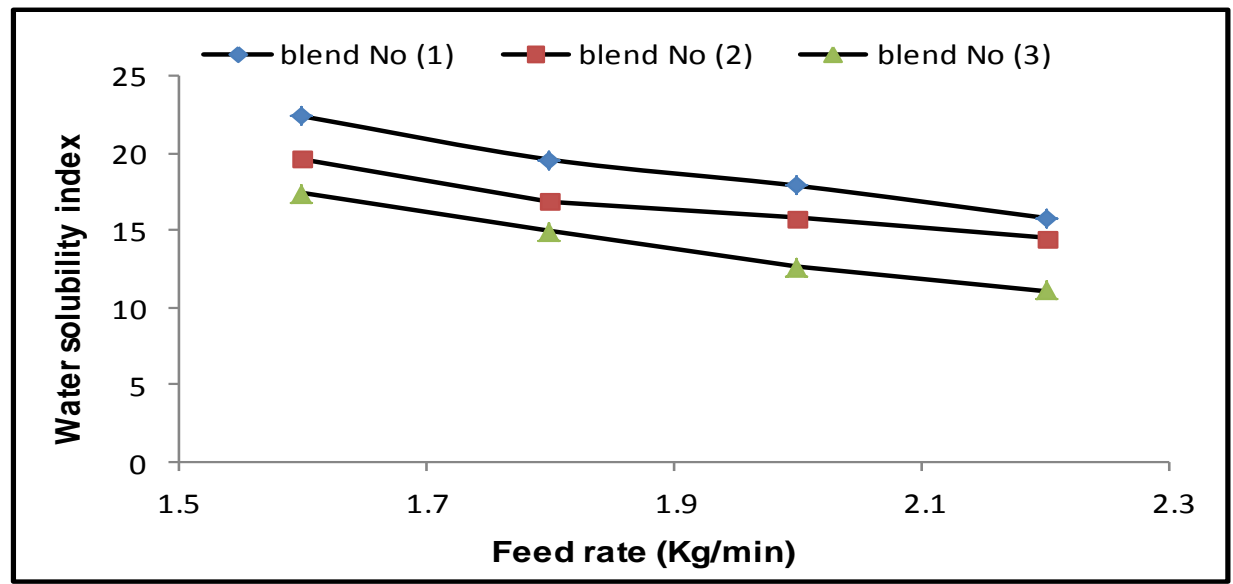

Fig.13. Effect of feeding rate on water solubility index of extrudates. 
Increasing carbohydrates may be due to the formation of amylase liquid complexes. This reaction could be confirmed by the decreasing percentage of fat. Fiber increasing may be due to the retrogression of starch which tern it to be very low susceptible to amylase and hence could be considered in dietary fiber rather than in the fraction of carbohydrate. Also, the increase in fiber may be referred to glucans percent in both soluble and insoluble fiber fractions including starch alterations the increase in lignin also occurred due millard reactions products. Ash increments could be due to the possibility that we are of the screw and barrel may enrich extruded foods (Sheard et al, 1984). Protean decreased attributed to the extrusion process this may due to the Millard reaction apt to occur due to high temperature and pressure in the existence of relatively high moisture percent.

Mean moisture content of the extrudates products ranged between 7.0 to $7.5 \%$ w.b. and data analyzed revealed insignificant between moisture content for different blends

One of limiting factors of consumer acceptability is the organoleptic properties including color, taste, crispness, appearance and overall acceptability. Data concerning the sensory evaluation scores of different products evaluated after extruded directly and after three months storage at room temperature.

Sensory evaluation results indicated that, the color and taste score was decreased with increasing the defatted soybean percentage.

The effect of storage on the sensory properties including (taste, appearance, crispiness and overall acceptability) was very slightly since the scores givenbefore and after storage were almost the same.

\section{CONCLUSSION}

1 - Increasing moisture content of feed material decreased the expansion rate while increasing both feed rate and screw speed increased the expansion rate of extrudates.

2- Increasing both moisture content and feed rate increased bulk density on contrary increasing screw speed decreased bulk density of extrudates

3 - Increasing moisture content increased water absorption index meanwhile increasing both screw speed and feed rate decreased water absorption index of extrudates 
4 - Increasing moisture content, screw speed and feed rate decreased water solubility index of extrudates

5 - Increasing protein percentage in the feed material increased bulk density and water absorption index but decreased expansion rate and water solubility of extrudates.

6 - the blends were able to increase the protein content in the extrudates products

7 - the single extruder gave satisfactory results with the blends sterilized by rice and soybean and provided percentage in extrudates products.

\section{REFERENCES}

Ahmed, A. S.; Ibrahim, N. A. Antiliafez, S.A. (1997). Biochemical evaluation for the effect of extruder temperature on soy protein. Food quality, 97(1) : 61-72

Almedia Dominguez, N.G.; Valencia, M.E. and Higera, I. (1990). Formulation of corn based snacks with high nutritive value, Biological sensory evaluation. J. Food St., 55(1): 228-231.

A.O.A.C. (1995) Association of Official Analytical Chemists (1995). 15 d., Published by A.O.A.C., 2200 Wilson Boulevard Arlington, Virginia 22201 U.S.A.

Bates, R.P.; Gvaham, H. O.; Matthews, R.F. and Close, L.R. (1991). Bread fruit chips: preparation, Stability and acceptability. J. Food Sci.. 56(6): 1680-1610.

Brncic, M.; Karlovic, S.; Bosijkov, T. Tripalo, Jezek, DandCugelj, I. (2008b). Enrichment of extruded snackproducts with whey proteins. Mijekarstvo, 58930, 275-295

Baskaran, V. and Bhattacharaya, S. (2004). Nutritional statuse of the protein of corn-soy based extruded products evaluated by rat bioassay. Plant Foods for Human Nutrition, 59, 101-104

Frame, N.D. (1994). The technology of extrusion cooking. Blacie Academic and Professional, An Lumprint of Chapman and Hall. WesterCleddens Road, BishopbiggesGlassow G642 Nz. Cited by Kabil, (2007) 
Gujska, E. and Khan, K. (1991). Effect of temperature on properties of extrudates from high - starch fraction of navy, pinto and garbanzo beans. J. Food Sci., 55(2): 466-469.

Hamza, A.B. (1997). Chemical and nutritional and characteristics of weaning foods prepared from cereal and legumes. Ph.D. thesis, Dept. of Food Sc. And Tech., Fac. Of Agric., Cairo University.

Kabil, E.M.. (2007) Technological and nutritional studied on some snacks. M.Sc. Thesis, Dept of Food Science, Faculty of Agric., Minoufiya University, Egypt

Manisha, C.; Zakiuddin, S. and Bhattacharya, S. (1997). Twin-screw extrusion of rice flour without adie: Effect of barrel temperature and screw speed on extrusion and extrudate characteristics. J. Food Eng. 32: 251-267.

Parks, L.L. and Carpenter, J.A. (1987). Functionality of six nonmeat protein in meat emusion systems., J. Food Sc., 52(2):271-274

Ragab, H. G. (1992). Production of some snacks foods through extrusion processing of some cereal and their products. Ph.D. Thesis. Dept. Food Science. Faculty of Agric., Alazhar Univ. Cairo, Egypt

Ryu, G.H., Walker, C.E. (1995) The effect of extrusion conditions on the physical properties of wheat flour extrudates. Starch/Starke 47, 3336.

Ryu, G.H., (2001). Effect of selected process parameters on expansion and mechanical properties of wheat flour and whole corn meal extrudates. Starch/Starke, 147-154

Saleh, S.S. (1996). Production and evaluation of extrudate from yellow corn grits blends. M.Sc. Thesis, Dept. of Food Sci. and Tec. Fac. Of Agric. Cairo University, Egypt

Santillan-Moreno, Marteniz, F.,Castano, E. and Amaya, S. (2009) Physicochemical characterization of extruded blends of corn 
starch-whey protein concentrate, Agave tequlana fiber. Food and Bioprocess technology, doi: 10.1007/s11947- 009-0223-x

Sheard, P. R. ; Ledward, D.A. and Mitheu, J. R. (1984). Role of carbohydrate in soybean extrusion, J. Food Tec. 19: 475-484

Stojceska, V.; Ainsworth, P. and Ibanoglu, S. (2009). The effect of extrusion cooking using different water feed rates on the quality of ready-to-eat snacks made from food by products. Food Chemistry, $114,226-232$.

Torun, B. Viteri, F.E. and Young, V.R. (1981). Nutritional role of soy a protein for humans., J. Am. Oil Chem. Soc. 58(3):400-406.

Wang, W.S. (1997). Starches an starch derivatives in expanded snacks. Cereal Food Warld. 42 (9): 743-745.

Weingartner, K.E.(1993). Nutrition of soybeans in (Soybeans processing for food uses) KukiatTanteeratarm Editor. Published by International Soybean Program, INTSOY Chmpaign U.S.A.

\section{الملخص العربي}

تأثثر عوامل التثغيل على الخواص الطبيعية للمنتجات المبثوقة عالية البروتين

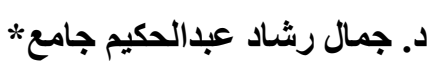

تم اعداد ثلاث خلطات بنسب مختلفة من مجروش الذرة الصفراء ومجروش الأرز و مجروش

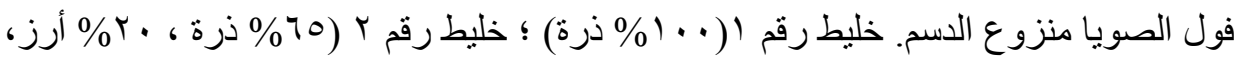

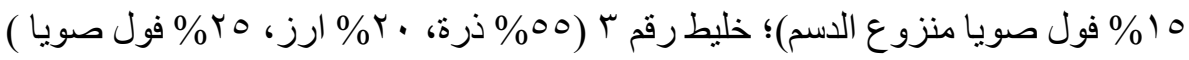

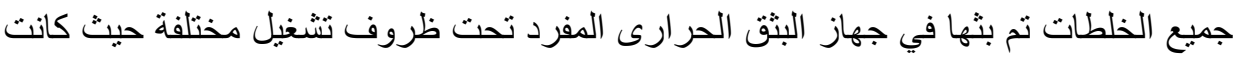

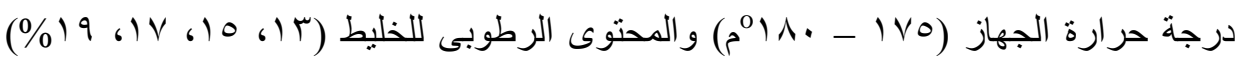

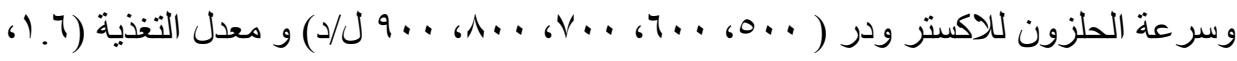

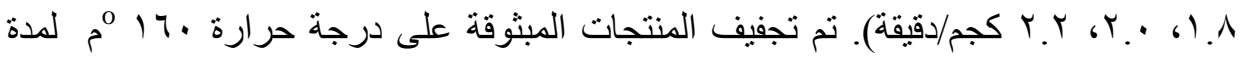
ثلاث دقائق وتمت در اسة الخو اص الطبيعية و الوظيفية للمنتجات و مدى تأثر ها بعو امل التشغيل

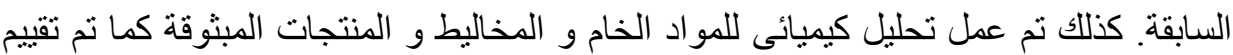

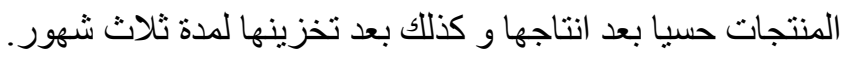

*استاذ مساعد بقسم الهندسة الزراعية ـ كلية الزراعة - جامعة المنوفية ـ مصر. 


\section{وتتلخص نتائج البحث كالآتي:}

ا ـ انخفض معدل التمدد للمنتجات المبثوقة بزيادة المحتوى الرئي الرطوبى للمخاليط بينما ازداد معدل

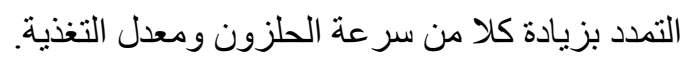

ץ. ازدادت الكثافة الظاهرية للمنتجات بزيادة كلا من المحتوى الرطوبى للمخاليط و معدل

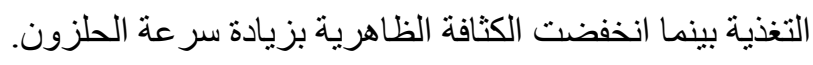

r. ازداد معدل امتصاص الماء للمنتجات بزيادة المحتوى الرطوبى بينما انخفض معدل

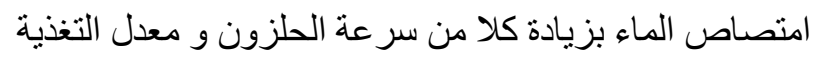

ع. انخفض معدل الذوبان في الماء بزيادة كلا من المحتوى الرطوبى و سرعة الحلزون و معدل التغذية

•. زيادة نسبة فول الصويا أدت لزيادة الكثافة الظاهرية و معدل امتصاص الماء بينما ادت

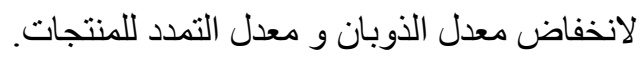

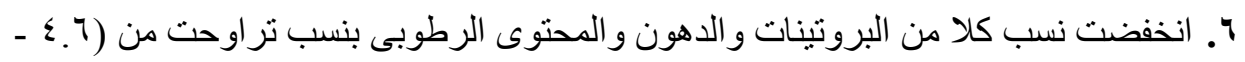

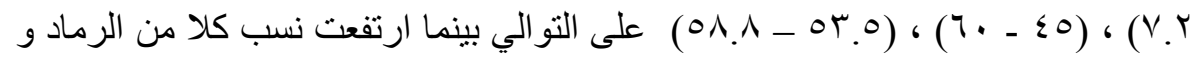

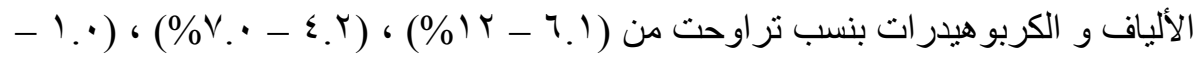

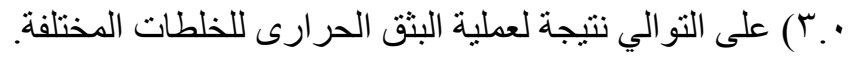

V. اظهر التقبيم الحسى(الطعم - المظهر - القوام - القبول العام) قبول عام للمنتجات وكان

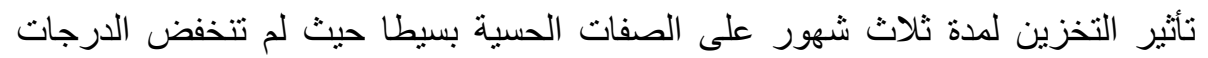

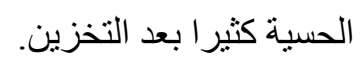

^. افضل عو امل للتشغيل من الممكن ان يوصى بها كانت 0 \%\% للمحتوى الرطوبى، . . ـ ل/د

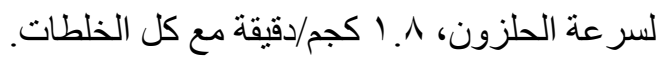

9. الخلطات مع البثق الحرارى امكنها زيادة محتوى الوجبات السريعة من البروتين وبالتالي

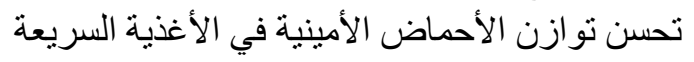

